\title{
Judging with a gender perspective in the CIVIL jurisdiction: Family issues, separation, divorce custodies and surnames registration
}

\author{
CARla Marina Lendaro \\ Judge at the Court of Appeal of Trieste \\ President of Italian Women Judges Association
}

I would like to thank you for inviting me to take part in this Conference and discuss such delicate, difficult and sensitive issues.

It is certainly a meaningful opportunity to dialogue with other magistrates colleagues coming from so many and different countries of the IAWJ European, Middle-east and African region. Over the past few decades, family laws have evolved everywhere, yet in different and various forms, and it is therefore more important to think on this change and the current situation. In my country, in Italy, following an early stage at the beginning of the past century, this path has started to come to life vigorously after the end of the Second World War. In that period women were given the right to vote and to play a full and active role in the community, which led the Italian society to innovate a transform, though very slowly.

In 1946 the Italian Constitution was promulgated, together with the important acknowledgment of fundamental rights.

This path brought up the relevance of a person as a "human being".

Thanks to the Constitution and its articles 29 and following sections, "Family law" became the center and most living part of Civil law.

Nevertheless, it took more than thirty years for such principles already consecrated by the Constitution to be effectively implemented.

Indeed, we had to wait until 1975 for the approval of the Italian "Family Law Reform" and until 1976 for the Italian "Divorce Law". It took even 40 years more, until 2012, for the full and complete recognition of "children" born outside of wedlock or in a marriage. Lastly, we had to wait until 2016 - only three years ago - for the acknowledgment and the regulation of heterosexual or homosexual "Civil Unions", as well as of the "Cohabitation Outside Marriage".

However, in Italy there is as yet no law for the "double-barreled surname" from both parents.

* Ponencia del «Justice with gender perspective». International Congress Program and 2nd Regional Conference IAWJ. Madrid 25th and 26th April 2019. 


\section{The transformation of women from subject to citizen has led Italy to innovate and transform, yet slowly.}

Society historically changes slowly, and this change takes place through a progressive and continuous mutation of culture and legal rules.

Over the last seventy years, starting from the end of the Second World War, in the Italian society changed not only the idea of "family", but also the patriarchal model changed radically.

The law has faced and still has to face this sweeping change in the future.

Laws are meant to uphold social intersubjective rights by respecting the right of equality: this is particularly important in family law, where rights are more often violated.

\section{It would be useful to recall that in the past many discriminations and inequalities were legitimate in Italy, to understand how many steps we have already taken.}

In the past, the husband was the "head of the household" and the one whom everyone had to obey. Every family relationship was based on a "power-submission scheme", which was characteristic of public law. The husband was supposed to protect his wife and to keep her by his side. The wife had to take her husband's surname and was obliged to stay with him wherever he wanted to establish his residence. Furthermore, she was not allowed to perform any relevant legal act "without" her husband's permission.

In case of death of the father, the authority seemingly transferred to the mother, who was however supported by a "family council" made of heirs, brothers and uncles of the orphan, who had an advisory function and gave authorizations.

The Adultery committed by a woman was a crime that justified a separation, the adultery by the husband, on the contrary, was not applicable to separation proceedings. In the past, it was not allowed to marry a citizen belonging to a "different race".

In the past, "legitimate" children were treated differently than "illegitimate" children: such form of discrimination was a burdensome criterion to divide categories and effects, like the exclusion to inheritance or acts of donation.

\section{This mutation became undeniable after the '50, the following booming economy, the fervour in schools and universities of 1968 and the reinforcement of women's movements.}

During those years, marriage was still indissoluble.

Only in 1965 was submitted a bill proposal that allowed a moderate form of "divorce" and the possibility to end the marriage after a 5-year separation. This proposal was followed by a long parliamentary process and, eventually, was passed to law on the 1st of December 1970 to regulate the cases of marriage dissolution. After this approval, the catholic world reacted submitting a signature collection for an "abrogative" referen- 
dum, that took place in May 1974, but it did not result in the expected affects: the large majority, the $59 \%$, voted against the abrogation.

One year later, thanks to the law No. 15 of the 19th of May 1975 concerning the "Reform of Family Law", the principals promulgated by the Constitution and its art. 29 were effectively implemented.

This reform modernised the "family" in terms of equality (Arts. 143, 144 and 147 of the civil code) establishing "rights and obligations" of the spouses. The head of the household disappeared, both spouses were obliged in equal proportions to work together in order to organise the family life and agree upon the family "residence". The "community property" was established (art. 177 of the civil code) and the previous "separation-ofproperty system" was abandoned - the latter could be chosen expressively by the spouses - as an acknowledgement of women's contribution to possession, maintenance and improvement of family goods. In matters of succession, thanks to this reform the spouse was considered as "heir" and not only usufructuary, to the extent of half of the properties in presence of one child, and of a third in presence of more children.

As far as children was concerned, the word "illegitimate children" for children outside marriage was no longer used, it was substituted by the word "natural children". However, they kept being treated differently with respect to other children, because for them existed no degree of "family relationship" legally. Finally, seven years ago, law No. 219 of 10th of December 2012 overcame this discrimination: today in Italy there is no difference among children, regardless if they were born or not in a marriage. According to family law, "children's best interest" always comes first and it is a responsibility of both parents to attend their needs, to educate them and take care of them depending on their own skills, talents and ambitions.

Also in those years, after the approval in 1978 of the law "Standards for social protection of motherhood and for voluntary interruption of pregnancy", and its confirmation after the abrogative referendum of the 17th of May 1981, abortion was allowed by law. Furthermore, honour killing provided by art. 587 of the penal code, was legally repealed by law No. 442 of August 10, 1981. Before that, the judgments of the Constitutional Court No. 126 of December 19, 1968 and No. 147 of December

3,1969 had declared unconstitutional the provisions of the penal code that provided the punishment of the adultery committed by the wife, and not the one committed by the husband.

\section{Times change and sometimes a change is followed by a further change.}

Over the past ten years, beside the already mentioned law promulgated in 2012, a series of other laws has been introduced that have completely evened out every child; in 2016 passed also a new law, that recognized both homosexual and heterosexual "Civil Unions" and "Non-Marital Cohabitation". 
In 2016 was introduced the "quick divorce" law, for which after six months of marital separation it is possible to divorce in limited time and expenditure by going to the town hall, in case the couple has no children. In case of children, on the other hand, you can opt for an "assisted negotiation" without taking action before the courts, but more practically proceeding with an extrajudicial settlement: lawyers have to regulate the various issues that then need to be "validate" by the prosecutor. A judgement is needed only when the agreement shows issues related to children.

\section{Family, women and society in Italy "today".}

The "traditional patriarchal family scheme" is not completely broken yet, and neither are women completely emancipated.

We still need to achieve a full equality.

Despite of the improvements in education and female presence growth in the world of work, in Italy only one-in-two women is employed (in Sicily is one-in-three). Moreover, women are paid $19 \%$ less in the private sector. Only few women fill a top- level management role in companies, universities, hospitals, and even inside the judiciary; in Italy there are too few women elected to fill political offices as well.

Many women have turn down motherhood because of their job or other offices. The price paid by women that renounce to the traditional model of the wife/mother woman is very high, especially in central and northern Italy.

Italian women carry such a heavy personal burden of work, family and household care, care for their children and elderly.

On the other hand, most of Italian men have not yet adapted completely to the "new" social and family needs brought by the change of the recent years. This may be attributed to the fact that Italian men are not ready yet, from a cultural point of view, to change their behavioural model or, maybe, they just push it back, wittingly or not. In the meanwhile, the Italian State has not provided for proper facilitations, neither for any other form of grant or assistance. In fact, it did the opposite.

\section{As I was saying, times change and a change is sometimes followed by a short slow- down or restoration, as occurred in Italy over the last year.}

The patriarchal model is deeply rooted and has a strong influence in our society.

After the radical mutation of the political context that took place in spring 2018, various draft laws towards the traditional model are taken into consideration. In the name of alleged "traditional" family values, these draft laws are strongly restorative and provide for taking the idea of family and consequently the status of women "back" in time and reviving the "ancient forms" of family relationships.

One of these upcoming measures is the so-called Pillon Bill, a law-decree that, in case of separation of a marriage with children, gives prevalence to the right of owner- 
ship of the marital home: children's custody is mathematically divided into equal periods for both parents and there is no provision of maintenance allowances for children, whose expenses have to be covered by the parent who has their custody. Therefore, the Pillon Bill does not take into consideration neither the gender-gap in wages - Italian women still have a lower income than men - nor the fact that women have to renounce too many times to their work activities to face household and family care, not mentioning the remote possibility to find a job in a "no longer young age". The bill provides for regulations that impose a mediation against payment before proceeding with the marital separation, also in case of partner violence, which clearly conflicts with the Istanbul Convention, that was yet ratified unanimously in 2014 by the Italian Parliament.

Last November the Italian Women Judges Association has expressed its legal opinion concerning this bill proposal upon request of the Minister of Justice in order to stress the emerged issues, which conflict with the current national and international legal provisions and the established interpretations in the jurisprudence. Then we have released this document in every branch of the national territory.

This year in Italy further bill proposals are still under evaluation, with provisions that question the rights acquired by women a long time ago: for instance, they amend law No. 194 of 1974 about "abortion", they question the family reform, they restore "brothels" for prostitution and provide for the elimination of "civil unions" for gays and lesbians and of the divorce.

We are experiencing in Italy the effort to erase a freedom that has been laboriously achieved over time by women and to resize the important social role of women, as already happened after the First World War.

A strong protest has been lodged with public demonstration on the streets - not only by women - against the mentioned legal measures.

\section{In closing, allow me to remember Simone de Beauvoir's warning:}

"Never forget that a political, economic or religious crisis will be enough to cast doubt on women's rights. These rights will never be vested. You'll have to stay vigilant your whole life."

In light of these strong words and the current situation in Italy, all Italian women, - women Judges among them - must remember that the path taken by women has been marked not only by steps forward, but also by few steps backwards before getting always back to the right way.

Despite the difficulties and obstacles, today we therefore must "go further" and never stop.

We must move forward together along the path we took; however hard it may be.

We must keep on moving together with conviction and determination towards the goal, our goal.

I thank you for your attention. Carla Marina Lendaro 